\title{
TNF- $\alpha$, IL-1 $\alpha$, IL-6 and ICAM-1 expression in human keratinocytes stimulated in vitro with Escherichia coli heat-shock proteins
}

\author{
Antonella Marcatili, ${ }^{1}$ Gabriella Cipollaro de I'Ero, ${ }^{1}$ Marilena Galdiero, ${ }^{1}$ \\ Antonio Folgore ${ }^{1}$ and Giulio Petrillo ${ }^{2}$
}

Author for correspondence: Antonella Marcatili. Tel: +3981 5665663. Fax: +39815665664.

Istituto di Microbiologia1 and Istituto di Clinica Dermosifilopatica2,

Seconda Università degli Studi di Napoli, Facoltả di Medicina e Chirurgia, Larghetto S.Aniello a Caponapoli, 2, 80138 Napoli, Italy

\begin{abstract}
Bacterial heat-shock proteins (HSPs) from Escherichia coli (GroES, GroEL and DnaK) were studied for their ability to induce by themselves the expression and release of tumour necrosis factor- $\alpha$ (TNF- $\alpha$ ), interleukin-1 $\alpha$ (IL-1 $\alpha$ ), interleukin-6 (IL-6) and intercellular adhesion molecule-1 (ICAM-1) by cultured human keratinocytes. The surface expression of ICAM-1 was also investigated. In the supernatants of untreated cells none or a minimal amount of these molecules was found. After $\mathbf{4 8} \mathrm{h}$ of stimulation with GroEL significant amounts of TNF- $\alpha$, IL-1 $\alpha$, IL-6 and soluble ICAM-1 were detected, reaching maximum concentrations at $1 \mu \mathrm{g} \mathrm{ml}^{-1}$. The same effect was elicited by DnaK but to a lesser extent. Treatment of keratinocytes with GroEL and DnaK also increased TNF- $\alpha$, IL-1 $\alpha$, IL-6 and ICAM-1 mRNA levels. GroES showed significant activity only on the expression and release of IL-6. GroEL and DnaK were also able to up-regulate the surface expression of ICAM-1 on keratinocytes. The effects on ICAM-1 expression seemed to be directly due to HSPs and not mediated via cytokines. Furthermore, these effects were due to the properties of HSPs because they were inhibited by specific monoclonal antibodies. These findings support the potential role of HSPs in modulating cell interactions during immunological and inflammatory responses in the skin.
\end{abstract}

Keywords: heat-shock proteins, TNF- $\alpha$, IL-1 $\alpha$, IL-6, ICAM-1

\section{INTRODUCTION}

Heat-shock proteins (HSPs) are evolutionarily highly conserved polypeptides with important biological functions in protein biogenesis (Georgopoulos \& Welch, 1993). They appear to be produced by prokaryotic and eukaryotic cells to preserve cellular functions under a variety of stress conditions, including heat-shock, nutrient deprivation, and viral and bacterial infections (Fayet et al., 1989; Kaufmann, 1990; Lindquist \& Craig, 1989; Pelham, 1988). These proteins are predominantly located in intracellular compartments but recent evidence suggests that some HSPs can be expressed on the cell surfaces and secreted extracellularly (Ensgraber \& Loss, 1992).

Recently, it has been shown that in vitro exposure of human monocytes to some HSPs induces the release of

Abbreviations: HSP, heat-shock protein; ICAM-1, intercellular adhesion molecule-1; IL-1 $\alpha$, interleukin-1 $\alpha$; IL-6, interleukin-6; LDH, lactate dehydrogenase; sICAM-1, soluble ICAM-1; TNF- $\alpha$, tumour necrosis factor- $\alpha$. proinflammatory cytokines, such as tumour necrosis factor- $\alpha$ (TNF- $\alpha$ ) and interleukin-1 $\beta$ (IL- $1 \beta$ ) (Georgopoulos \& Welch, 1993; Retzlaff et al., 1994; Zhang et al., 1993; Peetermans et al., 1995a), but little is known about the role of these proteins in the host protective response.

It is well-known that the mycobacterial HSP 65 , which belongs to the major $60 \mathrm{kDa}$ HSP family that displays a high degree of genotypic and phenotypic homology among various micro-organisms, is an immunodominant antigen able to elicit a strong humoral and cellular immune response (Peetermans et al., 1995a). HSP 65 homologues are abundantly expressed in inflammatory lesions and produced by micro-organisms during invasive infection and phagocytosis (Buchmeier \& Heffron, 1990; Peetermans et al., 1995b).

Our hypothesis is that HSPs are involved in the pathogenesis of various inflammatory diseases and add to a first-line host defence against invasive pathogens by their ability to induce the release of proinflammatory 
cytokines, which in turn activate antimicrobial functions of mononuclear phagocytes. The aim of this study was to assess whether different HSPs from Escherichia coli are able to induce TNF- $\alpha$, interleukin- $1 \alpha$ (IL- $1 \alpha$ ), interleukin-6 (IL-6) and intercellular adhesion molecule-1 (ICAM-1) expression and release by keratinocytes.

Epidermal cells, and in particular keratinocytes, have been recently recognized to play a central role in transmitting proinflammatory signals by secreting cytokines and growth factors (Luger \& Schwarz, 1990). The constitutive production of these factors, in particular IL1 and TNF- $\alpha$, is usually very low, but can be induced significantly by various injurious agents such as endotoxin, virus particles, tumour promoters or UV light (Luger \& Schwarz, 1990; Kupper, 1990; Köch et al., 1990). In the case of human keratinocytes, both IL- $1 \alpha$ and IL- $1 \beta$ are expressed, although IL- $1 \alpha$ is the major secreted isotype (Kupper, 1990).

IL-1 and TNF- $\alpha$ in their turn act with an autocrine mechanism on keratinocytes, inducing the release of a cascade of other cytokines which can have a proinflammatory or chemotactic activity (IL-6, IL-8, granulocyte-monocyte colony stimulating factor) and the expression of adhesion molecules, in particular ICAM-1 (Shalaby et al., 1984; Dinarello et al., 1986; Sauder et al. 1988; Groves et al., 1992; Trefzer et al., 1991; Nickoloff et al., 1991). ICAM-1 is expressed by a wide variety of cells (Dustin et al., 1986) and is able to initiate cellular interactions in the immune system.

The constitutive expression of ICAM-1 by keratinocytes is minimal but can be stimulated by several cytokines (interferon- $\tau$, TNF- $\alpha$ ). Furthermore, recent studies have demonstrated that a soluble form of ICAM-1 (sICAM1 ) is released during inflammatory reactions (Seth et al., 1991).

These molecules are not only involved in the mediation of local inflammatory reactions but also cause systemic effects. Thus it is of great interest to explore the various factors, especially bacterial components, able to induce in keratinocytes the expression and release of molecules which show biological activities, not only for the understanding of some skin diseases, but also to gain further insight into the role played by these cells in inflammatory and immune responses.

\section{METHODS}

E. coli HSPs. GroES, the $10 \mathrm{kDa}$ HSP (HSP 10) of E. coli, GroEL, the $60 \mathrm{kDa}$ HSP (HSP 60) of E. coli, and DnaK, the $70 \mathrm{kDa}$ HSP (HSP 70) of E. coli, were purchased from Boehringer Mannheim.

Keratinocyte cell cultures. Surgical foreskin specimens, obtained from young patients, were rinsed in PBS (0.145 sodium chloride, 0.15 sodium phosphate) with $10 \%$ penicillin/ streptomycin and $1 \%$ amphotericin B for $30 \mathrm{~min}$, washed in PBS and then incubated overnight in $1 \%$ dispase II (Boehringer Mannheim, $0.5 \mathrm{U} \mathrm{mg}^{-1}$ ) at $4{ }^{\circ} \mathrm{C}$ to cause epidermal separation. Epidermal sheets were treated with $0 \cdot 25 \%$ trypsin containing $0.34 \mathrm{M}$ EDTA. After $20 \mathrm{~min}$ incubation at $37^{\circ} \mathrm{C}$ under gentle agitation, the cells were centrifuged and resuspended in serum- free keratinocyte medium supplemented with recombinant epidermal growth factor $\left(5 \mathrm{ng} \mathrm{ml}^{-1}\right)$ and bovine pituitary extract $\left(50 \mu \mathrm{g} \mathrm{ml}^{-1}\right)$ (Gibco). The keratinocytes were plated into sterile 6-well plates and grown at $37^{\circ} \mathrm{C} 5 \% \mathrm{CO}_{2}$. Cells were trypsinized and replated into $250 \mathrm{ml}$ tissue culture flasks until primary cultures reached confluence. Cultures at their third or fourth passage were used in all subsequent studies (Walev et al., 1993). Immunofluorescent staining using monoclonal antibodies to keratins (Boehringer Mannheim), to Langerhans cells (OKT6, Ortho Pharmaceuticals), to melanocytes (S-100, Ortho), to lymphocytes (OKT3, Ortho) and to major histocompatibility complex class II antigen (HLA-DR) (OKDR, Ortho) verified that these cell cultures consisted of $100 \%$ keratinocytes and did not express HLA-DR antigen.

Induction of cytokine and sICAM-1 production. Keratinocytes $\left(3 \times 10^{6} \mathrm{ml}^{-1}\right)$ were incubated at $37^{\circ} \mathrm{C}$ in $5 \% \mathrm{CO}_{2}$ for up to $48 \mathrm{~h}$ either with HSPs diluted in the cell culture at the appropriate concentrations $(0 \cdot 05-5 \mu \mathrm{g} / \mathrm{ml})$ or with $E$. coli serotype O26:B6 LPS (1 $\mu \mathrm{g} \mathrm{ml}^{-1}$, Sigma). Pilot studies suggested that $48 \mathrm{~h}$ was the average release time. After contact, the culture supernatants were harvested for cytokine and sICAM-1 assays. Cell viability was then checked by the Trypan blue exclusion test. Cell stimulation was also performed with trypsinized HSPs. To this end, proteins were cleaved overnight at room temperature with immobilized trypsin (treated with $N$-tosyl-L-phenylalanine chloromethyl ketone and attached to beaded agarose; Sigma) (Koga et al., 1989).

Cytokine and sICAM-1 assays. All measurements were carried out by using monoclonal antibodies. TNF- $\alpha$, IL- 6, IL- $1 \alpha$ and ICAM-1 were measured by immunoenzymic methods (TNF$\alpha$ - and IL-6-ELISA, Biochrom; IL- $1 \alpha$ Quantikine, R \& D Systems; Soluble ICAM-1 ELISA kit, British Bio-technology).

Lactate dehydrogenase (LDH) assay. This was carried out according to the manufacturer's instructions using a Cytotoxicity Detection kit (Boehringer Mannheim). $\mathrm{LDH}$ is a stable cytoplasmic enzyme present in all cells and is rapidly released into the cell culture supernatant upon damage of the plasma membrane. LDH activity was determined by a coupled enzymic reaction whereby the tetrazolium salt (INT) was reduced to formazan. An increase in the number of dead or damaged cells resulted in an increase in LDH activity in the culture supernatant.

RNA isolation and CDNA preparation. Human keratinocytes $\left(1 \times 10^{7}\right)$, cultured in complete medium under different experimental conditions, were collected after $3 \mathrm{~h}$ and total RNA was extracted according to Chomczynski \& Sacchi (1987). The RNA pellet was resuspended in $75 \%$ ethanol, sedimented, vacuum-dried and dissolved in $15 \mu \mathrm{l}$ Rase-free water. One $\mu \mathrm{g}$ of oligo(dT) (Promega Biotec) was added to the suspension and the mixture was heated at $65^{\circ} \mathrm{C}$ for $5 \mathrm{~min}$. After cooling on ice the mixture was incubated for $2 \mathrm{~h}$ at $42^{\circ} \mathrm{C}$ with $14 \mu \mathrm{l}$ of the following mixture: $20 \mathrm{mM}$ DTT (Sigma); $1 \mathrm{mM}$ (each) dATP, dGTP, dCTP and dTTP; 35 U RNasin (Promega); and $525 \mathrm{U}$ of Moloney murine leukaemia virus reverse transcriptase (Gibco BRL) in reverse transcription buffer (Gibco BRL).

PCR procedure. PCR primers for human TNF- $\alpha$, IL- $1 \alpha$, IL-6 and $\beta$ actin were purchased from Clontech. Human ICAM-1 primer pair sequences were designed on the basis of published gene sequences as follows: sense, $5^{\prime}$-CGTGCCGCACTGAACTGGAC-3'; anti-sense, 5' -CCTCACACTTCACTGTCACCT $-3^{\prime}$. The primer sequences were complementary to sequences in the exons or spanned exon-exon junctions and 
thus were RNA-specific. Two microlitres of cDNA, prepared as described above, was amplified in the presence of $500 \mathrm{nM}$ (final concentration) $5^{\prime}$ and $3^{\prime}$ primers, $200 \mu \mathrm{M}$ (each) dATP, dGTP, dCTP and dTTP, and 1.25 U Taq DNA polymerase (Promega) in a final volume of $50 \mu \mathrm{l} \mathrm{Taq}$ DNA polymerase $10 \times$ buffer (Promega). The PCR was performed in a PerkinElmer thermal cycler for 30 cycles as follows: 1 min denaturation at $94^{\circ} \mathrm{C}, 2 \mathrm{~min}$ annealing at $60^{\circ} \mathrm{C}$ and $3 \mathrm{~min}$ extension at $72^{\circ} \mathrm{C}$. The reaction product was visualized by electrophoresis using $25 \mu \mathrm{l}$ of the reaction mixture at $100 \mathrm{~V}$ in $1.5 \%$ agarose gel containing ethidium bromide $\left(1 \mu \mathrm{g} \mathrm{ml}^{-1}\right)$. The gels were then examined on a UV light box and photographed. One microgram of Bgll- and Hinfl-digested pBR328 DNA (Boehringer Mannheim) was run in parallel as a molecular mass marker (providing bands at 2176, 1766, 1230, 1033, 653, $517,453,394,298,234,220$ and $154 \mathrm{bp}$ ).

PCR-assisted mRNA amplification was repeated at least twice for at least two separately prepared cDNA samples for each experiment; data shown are representative of at least three different experiments.

Up-regulation of membrane ICAM-1. Keratinocytes $\left(1 \times 10^{5}\right)$ were plated in 6-well tissue culture plates and incubated at $37^{\circ} \mathrm{C}$ overnight. The different HSPs were added 12, 24 and $48 \mathrm{~h}$ prior to staining the cells for ICAM-1.

After incubation at $37^{\circ} \mathrm{C}$ for different lengths of time, cells were rinsed twice with PBS, harvested by trypsinization and then processed for immunofluorescence analysis.

Previous experiments established that this method of cell harvesting does not affect the surface expression of any of the antigens studied when compared to non-enzymically harvested cells.

Surface ICAM-1 expression by keratinoctes was determined by indirect immunofluorescence. Collected and washed cells were incubated with a 1:40 dilution of the mouse anti-human ICAM-1/CD54 monoclonal antibody (Boehringer Mannheim) for $30 \mathrm{~min}$ at $4{ }^{\circ} \mathrm{C}$. Cells were then washed three times in PBS containing $0.05 \%$ sodium azide, resuspended and incubated with a 1:20 dilution of fluorescein-isothiocyanateconjugated goat anti-mouse IgG (Sigma). Subsequently, cells were washed three times and analysed using a Becton Dickinson FACS analyser (Becton Dickinson). Usually 5000 cells per sample were assessed and data are given as percentage ICAM-1-reactive cells in comparison to unstimulated control cells.

Blocking experiments. To verify whether the effects observed were due to the properties of HSPs they were inhibited by available specific monoclonal antibodies, which were added $\left(0.5 \mu \mathrm{g} \mathrm{m}^{-1}\right)$ to cell culture media immediately following stimulation by HSPs in each series of experiments. With this aim, monoclonal antibody anti-DnaK (clone 8E2) and antiGroEL (clone 9A1) (Stressgene Biotechnologies) were used. To assess whether the expression of ICAM-1 is a direct or indirect effect due to HSPs, monoclonal antibody anti-human TNF- $\alpha$, anti-human IL-1 $\alpha$ and anti-human IL- 6 obtained from Genzyme were used. To block ICAM-1 cytokine induction, the antibodies $\left(0.5 \mu \mathrm{g} \mathrm{ml}^{-1}\right)$ were added to cell culture media immediately following stimulation by bacterial components. The keratinocytes were incubated for the usual length of time before the amounts of cell surface and released ICAM-1 were assayed.

Statistics. All experiments were carried out in triplicate; results are expressed as means \pm SD. Comparisons between tests were done by the Student's $t$-test, with statistical significance considered to be $P<0.05$.

\section{RESULTS \\ Purity of HSP preparations}

All possible traces of LPS were identified by the Limulus amoebocyte lysate assay. This was performed with samples of each bacterial HSP and compared with standard LPS solution which was Limulus-amoebocytelysate-positive at $0.1 \mathrm{EU} \mathrm{ml}^{-1}\left(14 \mathrm{pg} \mathrm{ml}^{-1}\right)$. (QCL-1000 Quantitative Chromogenic LAL, Biowhittaker). All HSPs were negative in the Limulus amoebocyte lysate test at the concentrations used.

In addition, to neutralize the biological activity of traces of LPS that could be present in the preparation, HSPs were incubated with polymyxin B (Sigma) at room temperature for $1 \mathrm{~h}$ at a ratio of $1: 10$. In all of the tests performed, HSPs plus polymyxin B gave the same results as HSPs alone (data not shown).

Furthermore, because the cytokine-stimulating activity of HSPs is heat sensitive, HSPs were first inactivated by heating for $1 \mathrm{~h}$ at $90^{\circ} \mathrm{C}$ and then added to cell cultures. Heated HSPs had no effect on the expression and release of cytokines and ICAM-1 whereas LPS was fully active under the same experimental conditions (data not shown).

\section{TNF- $\alpha$ release}

Stimulation with some HSPs caused the appearance of TNF- $\alpha$ in the supernatant of keratinocyte cultures (Fig. 1a). Control cells incubated for $48 \mathrm{~h}$ revealed no significant release of TNF- $\alpha$. As expected, stimulation with LPS $\left(1 \mu \mathrm{g} \mathrm{ml}^{-1}\right)$ induced a marked release of TNF$\alpha$. Under our experimental conditions, TNF- $\alpha$ release was also induced by GroEL and DnaK extracted from $E$. coli, at concentrations ranging from 0.1 to $5 \mu \mathrm{g} \mathrm{ml}^{-1}$. The quantity of TNF- $\alpha$ released increased progressively up to GroEL and DnaK concentrations of $1 \mu \mathrm{g} \mathrm{ml}^{-1}$. Concentrations higher than this had no further effect on the production of TNF- $\alpha$ and concentrations lower than $0 \cdot 1 \mu \mathrm{g} \mathrm{ml}^{-1}$ GroEL and DnaK showed no significant effect. TNF- $\alpha$ release obtained using GroEL as a stimulus was similar to that induced by LPS at a concentration of $1 \mu \mathrm{g} \mathrm{ml}^{-1}$, while keratinocytes stimulated with DnaK showed a lower release. GroES had no significant effect on the release of TNF- $\alpha$ under the same experimental conditions. The release of TNF- $\alpha$ by keratinocytes stimulated with GroEL and DnaK was already detectable after $12 \mathrm{~h}$ incubation and reached its highest level after $48 \mathrm{~h}$ incubation (Table 1).

\section{IL-1 $\alpha$ release}

The release of IL- $1 \alpha$ by cultured keratinocytes stimulated with different HSPs is shown in Fig. 1(b). Controls incubated for $48 \mathrm{~h}$ revealed no significant amount of IL- 

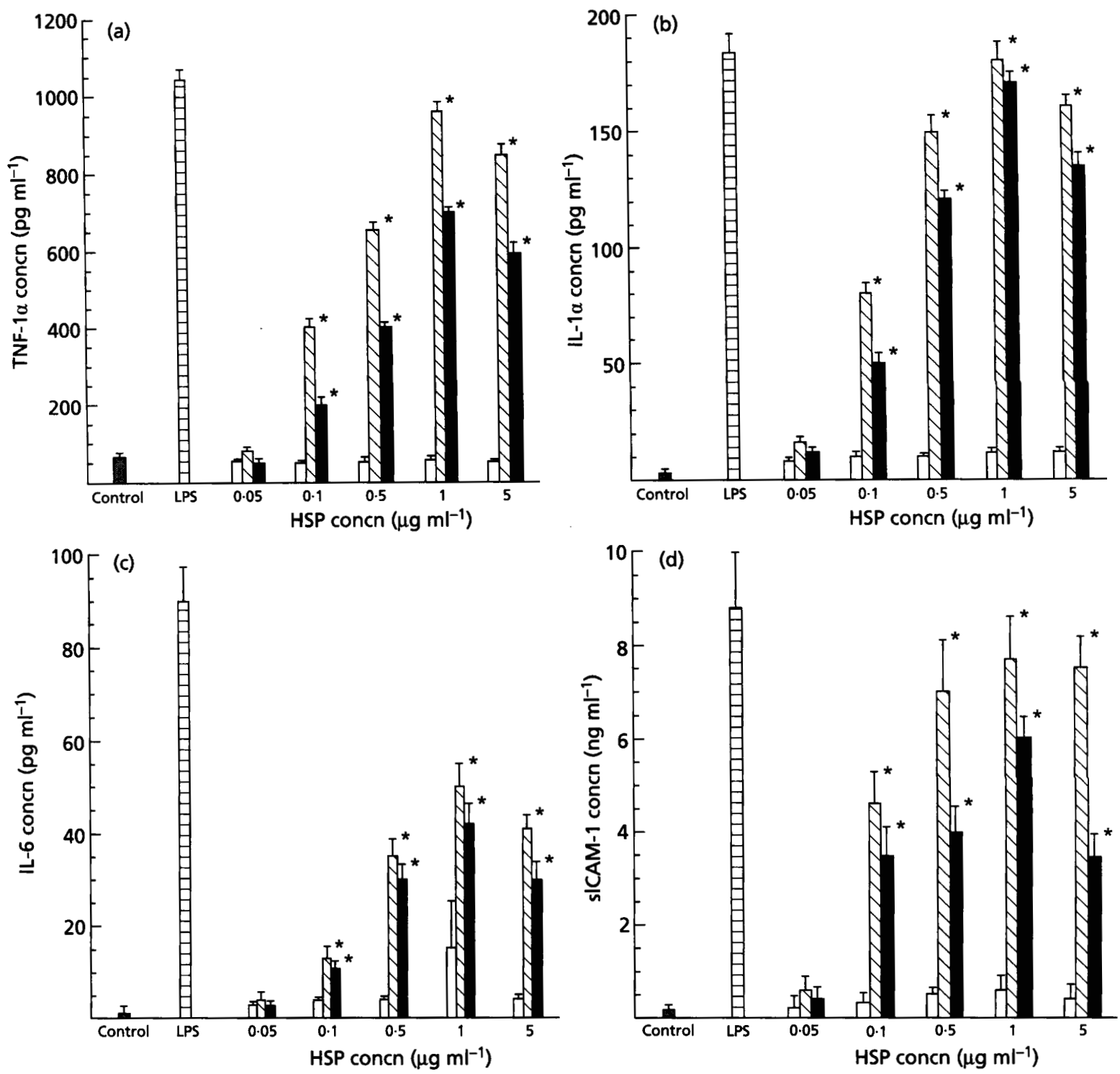

Fig. 1. Release of TNF- $\alpha$ (a), IL-1 $\alpha$ (b), IL-6 (c) and sICAM-1 (d) from human keratinocytes incubated for $48 \mathrm{~h}$ with GroES $(\square)$, GroEL $(\$)$ and DnaK $(\square)$ at different concentrations and with LPS $\left(1 \mu \mathrm{g} \mathrm{ml}^{-1}\right)(\boxminus)$. Results obtained with controls

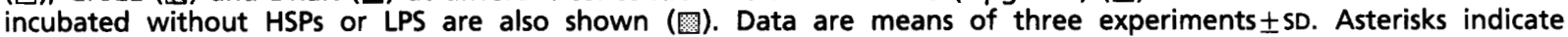
statistically significant differences $(P<0.05)$ versus untreated cells.

$1 \alpha$ release, while LPS-stimulated cells released high levels of IL1- $\alpha$. IL- $1 \alpha$ release was also induced by GroEL and DnaK at concentrations ranging from $0 \cdot 1$ to $5 \mu \mathrm{g} \mathrm{ml}^{-1}$. The quantity of IL1- $\alpha$ released increased progressively up to GroEL and DnaK concentrations of $1 \mu \mathrm{g} \mathrm{ml}^{-1}$. Thus the greatest release was obtained using the same concentrations that most effectively induced TNF- $\alpha$ release. Concentrations higher than $1 \mu \mathrm{g} \mathrm{m}^{-1}$ GroEL and DnaK had no further effect on the production of IL1- $\alpha$ and concentrations lower than $0 \cdot 1 \mu \mathrm{g} \mathrm{ml}^{-1}$ showed no significant effect. Keratinocytes treated with GroEL and DnaK were able to release IL- $1 \alpha$ in amounts similar to those obtained using LPS $\left(1 \mu \mathrm{g} \mathrm{ml}^{-1}\right)$ as a stimulus. No effect was detected when cells were treated with GroES at concentrations ranging from 0.05 to $5 \mu \mathrm{g} \mathrm{ml}^{-1}$. When GroEL and DnaK were used as a stimulus, IL- $1 \alpha$ appeared in the supernatant after $12 \mathrm{~h}$ and reached its highest level after $48 \mathrm{~h}$ incubation (Table 1).

\section{IL-6 release}

All the stimuli used induced IL- 6 release from keratinocytes in vitro (Fig. 1c). Controls incubated for $48 \mathrm{~h}$ revealed a slight IL- 6 release. LPS $\left(1 \mu \mathrm{g} \mathrm{ml}^{-1}\right)$ was a potent stimulus for IL-6 release. GroEL and DnaK were also able to induce significant IL-6 release starting at concentrations of $0 \cdot 1 \mu \mathrm{g} \mathrm{ml}^{-1}$ and reaching their maximum activity at $1 \mu \mathrm{g} \mathrm{ml}^{-1}$. GroES was able to induce significant IL-6 release only at concentrations higher 
Table 1. Kinetics of TNF- $\alpha$, IL- $\alpha$, IL- 6 and sICAM-1 release by human keratinocytes stimulated with $E$. coli HSPs

Keratinocytes were treated for up to $48 \mathrm{~h}$ with GroES $\left(1 \mu \mathrm{g} \mathrm{ml}^{-1}\right)$, GroEL $\left(1 \mu \mathrm{g} \mathrm{ml}^{-1}\right)$ and DnaK $\left(1 \mu \mathrm{g} \mathrm{ml}^{-1}\right)$. After 12, 24 and $48 \mathrm{~h}$ cell supernatants were harvested for cytokine and sICAM-1 assays. Data are means of three representative experiments \pm sD.

\begin{tabular}{|c|c|c|c|c|c|}
\hline & \multirow[t]{2}{*}{ Challenge } & \multicolumn{4}{|c|}{ Time (h) } \\
\hline & & 0 & 12 & 24 & 48 \\
\hline $\begin{array}{l}\text { TNF- } \alpha \text { concn } \\
\left(\mathrm{pg} \mathrm{m}^{-1}\right)\end{array}$ & $\begin{array}{l}\text { GroES } \\
\text { GroEL } \\
\text { DnaK }\end{array}$ & $\begin{array}{l}90 \pm 9 \cdot 6 \\
92 \pm 9 \cdot 5 \\
89 \pm 9 \cdot 4\end{array}$ & $\begin{array}{c}91 \pm 9 \cdot 7 \\
220 \pm 14 \cdot 8 \\
110 \pm 10 \cdot 5\end{array}$ & $\begin{array}{c}95 \pm 9 \cdot 7 \\
760 \pm 27 \cdot 5 \\
385 \pm 19 \cdot 6\end{array}$ & $\begin{array}{c}98 \pm 9 \cdot 8 \\
998 \pm 31 \cdot 6 \\
750 \pm 27 \cdot 3\end{array}$ \\
\hline $\begin{array}{l}\text { IL-1 } \alpha \text { concn } \\
\left(\mathrm{pg} \mathrm{ml}^{-1}\right)\end{array}$ & $\begin{array}{l}\text { GroES } \\
\text { GroEL } \\
\text { DnaK }\end{array}$ & $\begin{array}{l}6 \pm 2 \cdot 2 \\
5 \pm 2 \cdot 2 \\
6 \pm 2 \cdot 3\end{array}$ & $\begin{array}{r}7 \pm 2 \cdot 6 \\
32 \pm 5 \cdot 6 \\
22 \pm 4 \cdot 6\end{array}$ & $\begin{array}{c}11 \pm 3 \cdot 3 \\
135 \pm 11 \cdot 6 \\
128 \pm 12 \cdot 3\end{array}$ & $\begin{array}{c}15 \pm 3 \cdot 8 \\
187 \pm 13 \cdot 6 \\
175 \pm 13 \cdot 7\end{array}$ \\
\hline $\begin{array}{l}\text { IL-6 concn } \\
\left(\mathrm{pg} \mathrm{m}^{-1}\right)\end{array}$ & $\begin{array}{c}\text { GroES } \\
\text { GroEL } \\
\text { DnaK }\end{array}$ & $\begin{array}{l}3 \pm 1 \cdot 5 \\
4 \pm 2 \cdot 1 \\
3 \pm 1 \cdot 3\end{array}$ & $\begin{array}{r}5 \pm 2 \cdot 4 \\
15 \pm 3 \cdot 8 \\
7 \pm 2 \cdot 6\end{array}$ & $\begin{array}{r}8 \pm 2 \cdot 7 \\
43 \pm 6 \cdot 5 \\
28 \pm 5 \cdot 3\end{array}$ & $\begin{array}{l}16 \pm 3 \cdot 8 \\
52 \pm 7 \cdot 5 \\
43 \pm 6 \cdot 7\end{array}$ \\
\hline $\begin{array}{l}\text { sICAM-1 concn } \\
\left(\mathrm{ng} \mathrm{ml}^{-1}\right)\end{array}$ & $\begin{array}{l}\text { GroES } \\
\text { GroEL } \\
\text { DnaK }\end{array}$ & $\begin{array}{l}0 \cdot 2 \pm 0 \cdot 1 \\
0 \cdot 4 \pm 0 \cdot 3 \\
0 \cdot 3 \pm 0 \cdot 1\end{array}$ & $\begin{array}{l}0.5 \pm 0.3 \\
1.8 \pm 0.8 \\
1.3 \pm 0.7\end{array}$ & $\begin{array}{l}0.7 \pm 0.5 \\
3.2 \pm 1.5 \\
1.9 \pm 0.8\end{array}$ & $\begin{array}{l}0.7 \pm 0.4 \\
8 \cdot 2 \pm 2 \cdot 5 \\
6.4 \pm 2 \cdot 1\end{array}$ \\
\hline
\end{tabular}

than $1 \mu \mathrm{g} \mathrm{ml}^{-1}$. GroEL and DnaK used at concentrations higher than $1 \mu \mathrm{g} \mathrm{ml}^{-1}$ had no further effect on IL-6 release. The release of IL- 6 induced by HSPs was in all cases lower than that obtained after stimulation with LPS. IL-6 release from keratinocytes stimulated with HSPs revealed time kinetics similar to those obtained for TNF- $\alpha$ and IL- $1 \alpha$, showing the maximum level after $48 \mathrm{~h}$ incubation (Table 1).

\section{SICAM-1 release}

Of the stimuli assayed, LPS, GroEL and DnaK significantly increased the amount of sICAM-1 in the supernatant of cultured keratinocytes (Fig. 1d). Control cells incubated for $48 \mathrm{~h}$ showed no sICAM-1 release in the supernatants. GroEL and DnaK were able to induce significant sICAM-1 release starting at concentrations of $0 \cdot 1 \mu \mathrm{g} \mathrm{ml}^{-1}$ and reaching their maximum activity at $1 \mu \mathrm{g} \mathrm{ml}^{-1}$. Keratinocytes stimulated with GroEL $\left(1 \mu \mathrm{g} \mathrm{ml}^{-1}\right)$ released approximately the same amount of sICAM-1 as cells treated with LPS $\left(1 \mu \mathrm{g} \mathrm{m}^{-1}\right)$, while DnaK at the same concentration was able to induce a lower release. Treatment of keratinocytes with GroES at different concentrations $\left(0.05-5 \mu \mathrm{g} \mathrm{ml}^{-1}\right)$ caused no significant production of sICAM-1. When cells were treated with GroEL and DnaK, the release of sICAM-1 began after $12 \mathrm{~h}$ and the maximum release occurred after $48 \mathrm{~h}$ of incubation (Table 1).

\section{LDH assay}

The release of TNF- $\alpha$, IL- $1 \alpha$, IL- 6 and sICAM- 1 was not due to cell lysis; $\mathrm{LDH}$, as a cytoplasmic marker, was found to be present in the supernatant of stimulated cells at levels similar to those detected in the supernatant of unstimulated cells (data not shown).

\section{TNF- $\alpha$, IL-1 $\alpha$, IL-6 and ICAM-1 mRNA expression in human keratinocytes stimulated with HSPs}

Fig. 2 shows a representative gel containing the the reverse-transcription-PCR products of RNA extracted from HSP-treated keratinocyte cultures. Cells were stimulated with the HSP concentrations that showed the best activity in inducing the release of TNF- $\alpha$, IL- $1 \alpha$, IL6 and sICAM-1. The intensity of the signal from TNF$\alpha$, IL- $1 \alpha$, IL- 6 and sICAM- 1 mRNA increased when cells were treated with GroEL and DnaK $\left(1 \mu \mathrm{g} \mathrm{ml}^{-1}\right)$. Stimulation with GroEL and DnaK $\left(1 \mu \mathrm{g} \mathrm{ml}^{-1}\right)$ induced a similar expression of IL- $1 \alpha$ and IL- 6 mRNA, while GroEL was able to induce higher expression of TNF- $\alpha$ and ICAM-1 mRNA. Stimulation of keratinocytes with GroES $\left(1 \mu \mathrm{g} \mathrm{ml}^{-1}\right)$ induced a good expression only of IL6 mRNA. No effect on TNF- $\alpha$, IL- $1 \alpha$ and ICAM-1 mRNA was detected when cells were treated with GroES at concentrations ranging from 0.05 to $5 \mu \mathrm{g} \mathrm{m}^{-1}$.

\section{Up-regulation of ICAM-1 expression on keratinocyte surfaces}

As detected by flow cytometry, constitutive expression of ICAM-1 was low but expression was stimulated by LPS $\left(1 \mu \mathrm{g} \mathrm{ml}^{-1}\right)$, GroEL $\left(1 \mu \mathrm{g} \mathrm{ml}^{-1}\right)$ and DnaK $\left(1 \mu \mathrm{g} \mathrm{m}^{-1}\right.$ ) (Table 2). The increase of ICAM-1 levels began within $12 \mathrm{~h}$ of treatment, and this up-regulation continued for up to $48 \mathrm{~h}$. GroES showed no activity on ICAM-1 surface expression.

\section{Blocking experiments}

Monoclonal antibodies to TNF- $\alpha$, IL- $1 \alpha$ and IL- 6 did not significantly modify ICAM-1 expression and release 

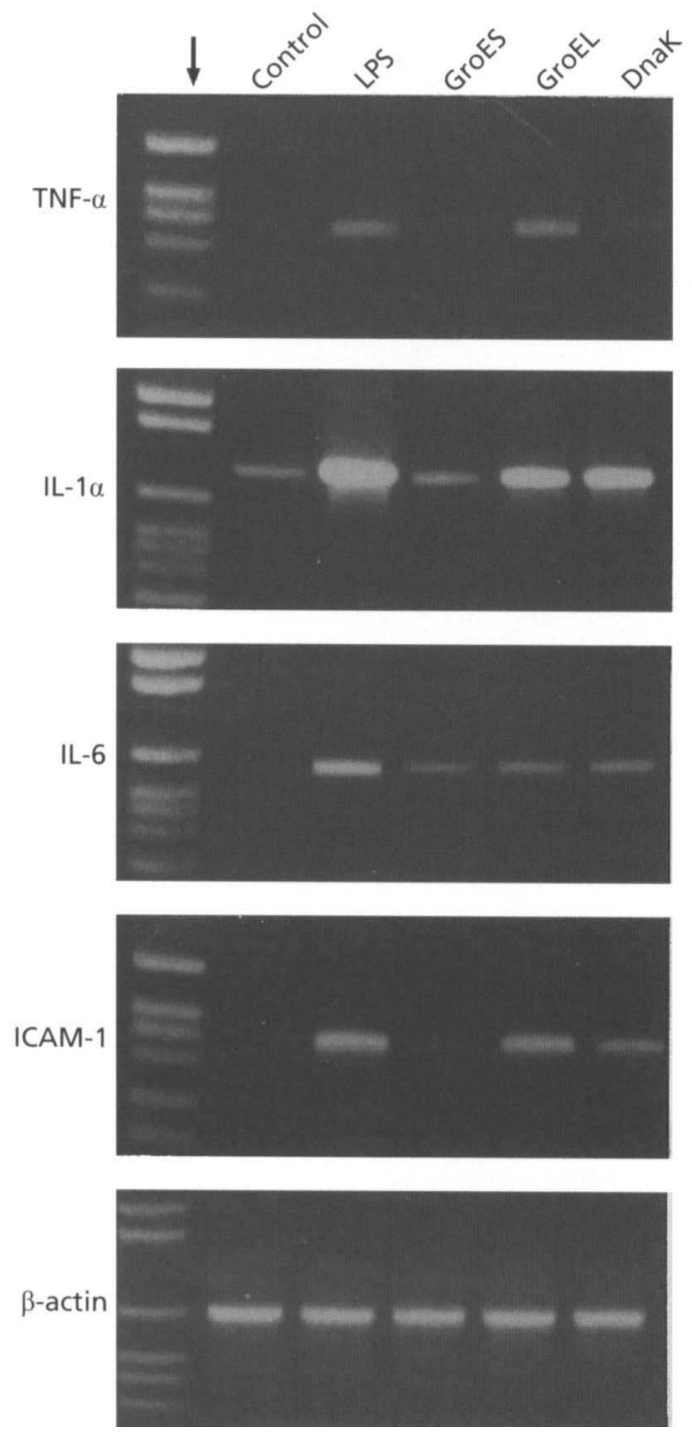

Fig. 2. Effect of HSPs on the steady-state levels of TNF- $\alpha, \mathrm{IL}-1 \alpha$, IL- 6 and ICAM-1 mRNA in human keratinocytes. Cultures were treated for $3 \mathrm{~h}$ either with culture medium (control), $E$. coli LPS $\left(1 \mu \mathrm{g} \mathrm{ml}^{-1}\right)$ or $E$. coli HSPs $\left(1 \mu \mathrm{g} \mathrm{ml}^{-1}\right)$ and then subjected to RNA extraction and reverse-transcription-PCR amplification. Reaction products were run on $1.5 \%$ agarose gels in the presence of appropriate molecular mass markers (arrow); $\beta$-actin was the positive transcription control.

in keratinocytes stimulated with LPS $\left(1 \mu \mathrm{g} \mathrm{ml}^{-1}\right)$, GroEL $\left(1 \mu \mathrm{g} \mathrm{ml}^{-1}\right)$ and DnaK $\left(1 \mu \mathrm{g} \mathrm{ml}^{-1}\right)$ (data not shown). Monoclonal antibodies anti-DnaK and anti-GroEL inhibited the biological activities shown by HSPs under our experimental conditions (data not shown).

\section{Cell stimulation with trypsinized HSPs}

To verify whether the stimulating activity of HSPs was protease-sensitive, all the tests were also performed using trypsinized HSPs as a stimulus. HSPs showed no biological activities under this experimental condition (data not shown).
Table 2. ICAM-1 surface expression after treatment with E. coli HSPs

Keratinocytes were treated for 12,24 and $48 \mathrm{~h}$ with LPS $\left(1 \mu \mathrm{g} \mathrm{ml}^{-1}\right)$, GroES $\left(1 \mu \mathrm{g} \mathrm{ml}^{-1}\right)$, GroEL $\left(1 \mu \mathrm{g} \mathrm{ml}^{-1}\right)$ and DnaK $\left(1 \mu \mathrm{g} \mathrm{ml}^{-1}\right)$. ICAM-1 surface expression was assessed by flow cytometry of 5000 cells per data point as described in Methods. Data are given as percentage ICAM-1-reactive cells in comparison to unstimulated control cells and are means of three representative experiments \pm SD.

\begin{tabular}{|lrrr|}
\hline Challenge & \multicolumn{3}{c|}{ Time (h) } \\
\cline { 2 - 4 } & \multicolumn{1}{c|}{12} & \multicolumn{1}{c|}{24} & \multicolumn{1}{c|}{48} \\
\hline None & $2 \pm 1$ & $3 \pm 1$ & $3 \pm 1$ \\
LPS & $18 \pm 5$ & $29 \pm 6$ & $27 \pm 4$ \\
GroES & $3 \pm 1$ & $5 \pm 2$ & $4 \pm 1$ \\
GroEL & $11 \pm 3$ & $24 \pm 5$ & $22 \pm 4$ \\
DnaK & $8 \pm 2$ & $19 \pm 3$ & $17 \pm 4$ \\
\hline
\end{tabular}

\section{DISCUSSION}

The HSPs, one of the most highly conserved group of proteins, are implicated as essential components in a number of different biological processes distinct from protein processing.

However, the role played by HSPs during the host response has not been yet clarified. A wide variety of stimuli such as temperature (Lindquist \& Craig, 1989), oxygen radicals $\left(\mathrm{H}_{2} \mathrm{O}_{2}\right)$ (Clerget \& Polla, 1990) and cytokines (Gromkowski et al., 1989) are able to increase the synthesis and production of HSPs. It is likely that, at the inflammatory site, lysis of bacterial cells may cause HSP accumulation. These proteins, by themselves or together with other molecules which show biological activities, could interact with host cells involved in the specific and non-specific responses affecting their functions (Karlsson-Parra et al., 1990; Polla, 1988; Kaufmann et al., 1991). Therefore, in this work we evaluated the effect of E. coli HSPs with different molecular masses on the expression and release of some cytokines (TNF$\alpha$, IL- $1 \alpha$ and IL-6) and of one adhesion molecule (ICAM1) in human keratinocytes.

In the inflammatory reaction of the skin, keratinocytes play a determining role by synthesizing and secreting cytokines and adhesion molecules (Koch et al., 1990; Partridge et al., 1991; Singer et al., 1989). Cytokines have pleiotropic effects on a wide range of cell types, and influence keratinocytes by modifying the secretion pattern of cytokines and other growth factors (Luger $\&$ Schwarz, 1990; Arai et al., 1990). Moreover, the adhesion molecules select the blood cells that are in turn activated locally, amplifying and modulating the inflammatory response by secreting soluble factors (Shalaby et al., 1984; Marlin \& Springer, 1987).

Our study demonstrated that among HSPs, GroEL and, to a lesser extent DnaK, were able to induce the release 
of TNF- $\alpha$, IL- $1 \alpha$, IL- 6 and sICAM- 1 from keratinocytes at concentrations ranging from $0 \cdot 1$ to $5 \mu \mathrm{g} \mathrm{ml}^{-1}$, with a maximum activity at $1 \mu \mathrm{g} \mathrm{m}^{-1}$. GroES showed significant activity only on the expression and release of IL-6.

The release of these molecules was not due to cell lysis; $\mathrm{LDH}$, as a cytoplasmic marker, was found to be present in the supernatant of stimulated cells at levels similar to those detected in the supernatant of unstimulated cells (data not shown). Keratinocytes also exhibited an increase in ICAM-1 surface expression after treatment with GroEL and DnaK. Our results show that surface expression of ICAM-1 on keratinocytes treated with GroEL and DnaK began to increase after $12 \mathrm{~h}$, reaching maximum levels after $24 \mathrm{~h}$ stimulation. All these findings were confirmed by reverse-transcription-PCR analysis of total RNA extracted from keratinocytes treated with the $E$. coli HSPs.

The effects on ICAM-1 expression seem to be directly due to HSPs and not mediated via cytokines because monoclonal antibodies anti-human TNF- $\alpha$, anti-human IL- $1 \alpha$ and anti-human IL-6, used to block ICAM-1 cytokine induction, did not modify the adhesin surface expression induced by HSP treatment.

The main conclusion of this study is that DnaK and GroEL by themselves induce activation of human keratinocytes as demonstrated by their ability to express and release cytokines and ICAM-1.

These effects must be due to the properties of HSPs since they are inhibited by specific monoclonal antibodies. Furthermore, trypsinized HSPs showed no biological activities.

The effects of HSPs cannot be due to LPS contamination. Control experiments carried out using polymyxin B to neutralize traces of LPS that could be present in HSP preparations gave the same results as HSPs used alone. In addition, we performed all the tests using heatinactivated HSPs. HSPs lost their activity under this experimental condition, while LPS was fully active.

The mechanisms involved in this process are not clear, but a possibility is the binding of HSPs to cell surface receptors. In fact, it is well-known that HSPs have a high affinity for immature or partially denatured proteins, binding them for the process of protein folding and unfolding (Hemmingsen et al., 1988). The reason for the relatively lower potency of GroES in comparison with the other HSPs is not clear. An explanation might be related to the relatively small size of this protein $(10 \mathrm{kDa})$ which prevents it from effectively cross-linking receptors following binding.

Our findings also suggest that HSPs may play an important role during inflammatory responses regulating the expression of molecules involved in the activation and adhesion of leukocytes.

The cytokines studied, along with sICAM-1, stimulate and select the cells involved in the immune response, such as T-cells and B-cells. Consequently, by releasing such factors, keratinocytes may intervene in regulating the local immune response. A higher release of such factors, especially TNF- $\alpha$, can be locally toxic to the host, which is best demonstrated by the crucial role of TNF- $\alpha$ in the pathogenesis of endotoxic shock in sepsis (Cerami \& Beutler, 1988). In addition to a number of cytokines and growth factor receptors (Kohno et al., 1990), soluble forms of adhesion molecules can also be released; L-selectin is released from the surface of neutrophils in response to a chemotactic stimulus (Smith et al., 1991) and P-selectin is released from platelets (Dunlop et al., 1992).

The potential function of soluble forms of adhesion molecules is at present the subject of speculation. Release from the cell surface may be a mechanism for down-regulating cytokine-induced increases in expression. Soluble molecules may function as competitive inhibitors of membrane-bound forms, thereby regulating cell adhesion. This has been demonstrated for a soluble form of P-selectin which is able to inhibit the adhesion of activated neutrophils to endothelial cells (Gamble et al., 1990). Soluble forms may have cytokinelike activity. Evidence to support such a role comes from the demonstration that recombinant soluble E-selectin can act as a chemoattractant (Lo et al., 1991). In addition, surface-bound ICAM-1 is able to have costimulatory effects on T-cells (Damle \& Aruffo, 1991) and it is possible that soluble forms may also have a cellsignalling role.

Taken together, our results support the crucial role of HSPs in the pathogenesis of both local and systemic responses of the skin against micro-organisms. Further investigations on effector and regulatory functions of HSPs in other host and microbial systems should clarify the mechanisms involved in host-parasite relationships.

\section{REFERENCES}

Arai, K., Lee, F., Miyajima, A., Shoichiro, M., Arai, N. \& Yokota, T. (1990). Cytokines: coordinators of immune and inflammatory responses. Annu Rev Biochem 59, 783-793.

Buchmeier, N. A. \& Heffron F. (1990). Induction of Salmonella stress proteins upon infection of macrophages. Science 248, 730-732.

Cerami, A. \& Beutler, B. (1988). The role of cachectin/TNF in endotoxic shock and cachexia. Immunol Today 9, 28-31.

Chomczynski, P. \& Sacchi, N. (1987). Single-step method of RNA isolation by acid guanidinium thiocyanate-phenol-chloroform extraction. Anal Biochem 162, 156-159.

Clerget, M. \& Polla, B. S. (1990). Erythrophagocytosis induces heat shock protein synthesis by human monocytes-macrophages. Proc Natl Acad Sci USA 87, 1081-1085.

Damle, N. K. \& Aruffo, A. (1991). Vascular cell adhesion molecule 1 induces T-cell antigen receptor-dependent activation of $\mathrm{CD}^{+} \mathrm{T}$ lymphocytes. Proc Natl Acad Sci USA 88, 6403-6407.

Dinarello, C. A., Cannon, J. C., Wolff, S. M., Bernheim, H. A., Beutler, B., Cerami, A., Figari, I. S., Palladino, M. A., Jr \& O'Connor, J. V. (1986). Tumor necrosis factor (cachetin) is an endogenous pyrogen and induces production of Interleukin-1. $J$ Exp Med 163, 1433-1450.

Dunlop, L. C., Skinner, M. P., Bendall, L. J., Favaloro, J., Castaldi, P. A., Gormann, J. J., Gamble, J. R., Vadas, M. A. \& Berndt, M. C. 
(1992). Characterization of GMP-140 (P-selectin) as a circulating plasma protein. J Exp Med 175, 1147-1150.

Dustin, M. L., Rothlein, R., Bhan, A. K., Dinarello, C. A. \& Springer, T. A. (1986). Induction by IL-1 and interferon gamma, tissue distribution, biochemistry and function of a natural adherence molecule (ICAM-1). J Immunol 137, 245-254.

Ensgraber, M. \& Loss, M. (1992). A 66-kilodalton heat shock protein of Salmonella typhimurium is responsible for binding of the bacterium to intestinal mucus. Infect Immun 60, 3072-3078.

Fayet, O., Ziegelhoffer, T. \& Georgopoulos, C. (1989). The groES and groEL heat shock gene products of Escherichia coli are essential for bacterial growth at all temperatures. J Bacteriol 171, 1379-1385.

Gamble, J. R., Skinner, M. P., Berndt, M. C. \& Vadas, M. A. (1990). Prevention of activated neutrophil adhesion to endothelium by soluble adhesion protein GMP 140. Science 249, 414-417.

Georgopoulos, C. \& Welch, W. J. (1993). Role of the major heat shock proteins as molecular chaperones. Annu Rev Cell Biol 9, 601-634.

Gromkowski, S. H., Yagi, J. \& Janeway, C. A. Jr (1989). Elevated temperature regulates tumor necrosis factor-mediated immune killing. Eur J Immunol 19, 1709-1714.

Groves, R. W., Ross, E., Barker, J. N. W. N., Ross, J. S., Camp, R. D. R. \& MacDonald, D. M. (1992). Effect of in vivo interleukin-1 on adhesion molecule expression in normal human skin. $J$ Invest Dermatol 98, 384-387.

Hemmingsen, S. M., Woolford, C., Van der Vies, S. M., Tilly, K., Dennis, D. T., Georgopoulos, C. P., Hendrix, R. W. \& Ellis, R. J. (1988). Homologous plant and bacterial proteins chaperone oligomeric protein assembly. Nature 333, 330-334.

Karlsson-Parra, A., Söderström, K., Ferm, M., Ivanyi, J., Kiessling, R. \& Klareskog, L. (1990). Presence of human $65 \mathrm{kD}$ heat shock protein (hsp) in inflamed joints and subcutaneous nodules of RA patients. Scand J Immunol 31, 283-288.

Kaufmann, S. H. E. (1990). Heat shock proteins and the immune response. Immunol Today 11, 129-136.

Kaufmann, S. H. E., Schoel, B., Van Embden, J. D. A., Koga, T., Wand-Württenberger, A., Munk, M. E. \& Steinhoff, U. (1991). Heat shock protein 60: implications for pathogenesis of and protection against bacterial infections. Immunol Rev 121, 67-90.

Köch, A., Schwarz, T., Kirnbauer, R., Urbanski, A., Perry, P., Ansel, J. C. \& Luger, T. A. (1990). Human keratinocytes are a source for tumor necrosis factor $\alpha$ : evidence for synthesis and release upon stimulation with endotoxin or ultraviolet light. J Exp Med 172, 1609-1614.

Koga, T., Wand-Wurttenberger, A., DeBruyn, J., Munk, M. E., Schoel, B. \& Kaufmann, S. H. E. (1989). T cells against a bacterial heat shock protein recognize stressed macrophages. Science $\mathbf{2 4 5}$, 1112-1115.

Kohno, T., Brewer, M. T., Baker, S. L., Schwartz, P. E., King, P. E., Hale, K. K., Squires, C. H., Thompson, C. H. \& Vannice, J. N. (1990). A second tumor necrosis factor receptor gene product can shed a naturally occurring tumor necrosis factor inhibitor. Proc Natl Acad Sci USA 87, 8331-8335.

Kupper, T. S. (1990). The role of epidermal cytokines. In The Immunophysiology of Cells and Cytokines, pp. 285-306. Edited by J. J. Oppenheim \& E. Shevach. New York: Oxford University Press.

Lindquist, S. \& Craig, E. A. (1989). The heat-shock proteins. Annu Rev Genet 22, 631-637.

Lo, S. K., Lee, S., Ramos, R. A., Lobb, R., Rosa, M., Chi-Rosso, G. \& Wright, S. D. (1991). Endothelial-leukocyte adhesion molecule 1 stimulates the adhesive activity of leukocyte integrin CR3 (Cd11b/CD18, Mac-1, $\alpha \mathrm{m} \beta$ 2) on human neutrophils. $J$ Exp Med 173, 1493-1500.

Luger, T. A. \& Schwarz, T. (1990). Evidence for an epidermal cytokine network. J Invest Dermatol 95, 1005-1011.

Mannel, D. N., Moore, R. N. \& Mergenhagen, S. E. (1990). Macrophages as a source of tumoricidal activity (tumor-necrotizing factor). Infect Immun 30, 523-530.

Marlin, S. D. \& Springer, T. A. (1987). Purified intercellular adhesion molecule 1 (ICAM-1) is a ligand for lymphocyte function associated antigen 1 (LFA-1). Cell 51, 813-819.

Nickoloff, B. J., Karabin, G. D., Barker, J. N. W. N., Griffiths, C. E. M., Sarrua, V., Mitra, R. S., Elder, J. T., Kruker, S. L. \& Dikit, V. M. (1991). Cellular localization of interleukin-8 and its inducer, tumor necrosis factor-alpha in psoriasis. Am J Pathol 138, 129-134.

Partridge, M., Chantry, D., Turner, M. \& Feldmann, M. (1991). Production of interleukin-1 and interleukin- 6 by human keratinocytes and squamous cell carcinoma cell lines. J Invest Dermatol 96, 771-776.

Peetermans, W. E., Raats, C. J. I., van Furth, R. \& Langermans, J. A. M. (1995a). Mycobacterial 65-kilodalton heat shock protein induces tumor necrosis alpha and interleukin 6 , reactive nitrogen intermediates, and toxoplasmatic activity in murine peritoneal macrophages. Infect Immun 63, 3454-3458.

Peetermans, W. E., D'Haens, G. R., Ceuppens, J. L., Rutgeerts, P. \& Geboes, K. (1995b). Mucosal expression by B7-positive cells of the 60 -kilodalton heat-shock protein in inflammatory bowel disease. Gastroenterology 108, 75-82.

Pelham, H. (1988). Heat-shock proteins. Coming in from the cold. Nature 332, 776-777.

Polla, B. S. (1988). A role for heat shock proteins in inflammation? Immunol Today 5, 134-137.

Retzlaff, C., Yamamoto, Y., Hoffman, P. S., Friedman, H. \& Klein, T. W. (1994). Bacterial heat shock proteins directely induce cytokine mRNA and interleukin-1 secretion in macrophage cultures. Infect Immun 62, 5689-5693.

Sauder, D. N., Stanulis-Praeger, B. M. \& Gilchrest, B. A. (1988). Autocrine growth stimulation of human keratinocytes by epidermal cell-derived thymocyte-activating factor: implications for skin aging. Arch Dermatol Res 280, 71-76.

Seth, R., Raymond, F. D. \& Makgoba, M. W. (1991). Circulating ICAM-1 isoforms: diagnostic prospects for inflammatory and immune disorders. Lancet 338, 83-84.

Shalaby, M. R., Aggarwall, B. B., Rinderknecht, E., Svedersky, L. P., Finkle, B. S. \& Palladino, M. A., Jr (1984). Activation of human polymorphonuclear neutrophil functions by interferon-gamma and tumor necrosis factor. J Immunol 135, 2069-2073.

Singer, K. H., Tuck, D. T., Sampson, H. A. \& Hall, R. P. (1989). Epidermal keratinocytes express the adhesion molecule intercellular adhesion molecule- 1 in inflammatory dermatoses. J Invest Dermatol 93, 746-750.

Smith, C. W., Kishimoto, T. K., Abbass, O., Hughes, B., Rothlein, R., McIntire, L. V., Butcher, E. \& Anderson, D. C. (1991). Chemotactic factors regulate lectin adhesion molecule 1 (LECAM-1)dependent neutrophil adhesion to cytokine-stimulated endothelial cells in vitro. $J$ Clin Invest 87, 609-618.

Trefzer, U., Brockhaus, M., Loetscher, H., Parlow, F., Kapp, A., Sch bpf, E. \& Krutmann, J. (1991). 55-kd tumor necrosis factor receptor is expressed by human keratinocytes and plays a pivotal role in regulation of human keratinocyte ICAM-1 expression. J Invest Dermatol 97, 911-916. 
Walev, I., Martin, E., Jonas, D., Mohamadzadeh, M., MullerKlieser, W., Kunz, L. \& Bhakdi, S. (1993). Staphylococcal alphatoxin kills human keratinocytes by permeabilizing the plasma membrane for monovalent ions. Infect Immun 61, 4972-4979.

Zhang, Y., Doerfler, M., Lee, T. C., Guillemin, B. \& Rom, W. (1993).

Mechanisms of stimulation of interleukin-1 $\beta$ and tumor necrosis factor- $\alpha$ by Mycobacterium tuberculosis components. J Clin Invest 91, 2076-2083.

Received 22 May 1996; revised 27 August 1996; accepted 4 September 1996. 